\title{
Sustainable Development in the Light of the Teachings of the Encyclical Laudato Si
}

\author{
Reginald Alva*
}

\begin{abstract}
Pope Francis' encyclical Laudato Si is a part of the Church's Magisterium. However, it contains deep insights, which encourage sustainable development of our planet. It includes everyone and everything, as all are inter-related. The contemporary world does not lack scientific studies on the problems of the earth. However, scientific studies are not sufficient to find concrete solutions to the problems, which humanity is facing. Even though, the encyclical does not claim to be a scientific document on ecology, it raises our attention to look into the problems of our planet and resolve to deal with them holistically. In this paper, we shall examine the suggestions in the encyclical Laudato $\mathrm{Si}$, which call upon the whole humanity to come together to work towards sustainable development of our planet. We shall compare the scientific concept of sustainable development with Pope Francis' understanding of the same term. Our sources for study will be the encyclical, other documents of the Church on similar subject and opinions of experts in this field.
\end{abstract}

Keywords: Laudato Si, Sustainable development, social dimension, ethical standards.

\section{Introduction}

The etymology of the word, environment is partly from the French word environner. It means "The action of circumnavigating, encompassing, or surrounding something; the state of being encompassed or surrounded."1 In other words, environment means to inter-relate. Pope Francis too notes in the first paragraph of his encyclical Laudato Si (LS) that earth is our common home. Home is the dwelling place of a family. All the members of the family have relation with one another. Pope Francis emphasizes the inter-connectedness of everything on earth. 2 Thus, the concern for the other is the keynote message of the encyclical.

In the contemporary world, political leaders, economists, scientists and industrialists are aware of the damage done to the environment and humanity in the name of progress. The world community is proposing sustainable development as a way to reduce the harm done to our planet. Pope Francis too advocates for sustainable development. In this paper, we shall examine Pope Francis' concept of sustainable development and compare it with the scientific concept of the same term.

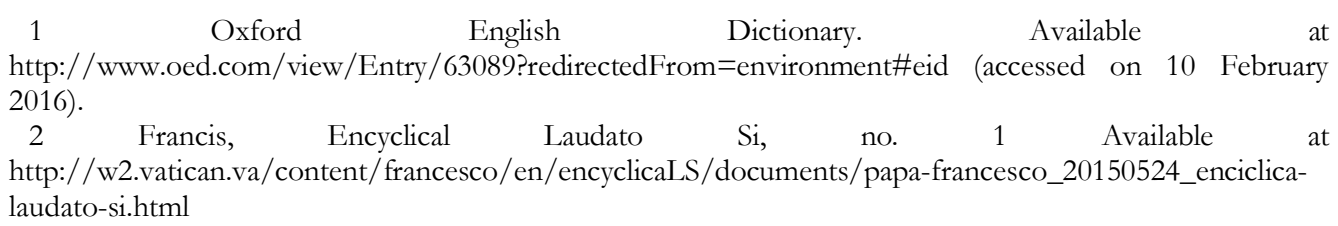




\section{Scientific Concept of the term Sustainable Development}

The contemporary people usually refer to the term sustainable development while discussing or dealing with issues related to environment, ecology and ecosystems. Encyclopedia of Environmental Ethics and Philosophy notes, "Sustainable development is designed to meet present needs without compromising the needs and aspirations of future generations." ${ }^{3}$ In 60 s and 70 s scientists referred to the environment-development link to human well-being as the subject matter of sustainable development. However, in the $80 \mathrm{~s}$ and the $90 \mathrm{~s}$, there was a shift in this understanding. Scientists began to expand the scope of sustainable development and considered it from a holistic perspective. Thus, sustainable development covered not only the environmental issues but also social, cultural and economic issues because all these fields are inter-related. ${ }^{4}$

The United Nations General Assembly established United Nations Commission on Sustainable Development in 1992 as a follow-up program of the United Nations Conference on Environment and Development (UNCED), also known as Earth Summit. ${ }^{5}$ In December 2015, government representatives of over 190 countries met at Paris to finalize a new international agreement on climate change under the United Nation Framework Convention on Climate Change (UNFCCC). Thus, the world community realizes the importance of curbing the ill effects of climate change. However, the problem arises in the implementation of the various policies adopted at the world convention on climate change.

\section{Sustainable Development in Laudato Si}

In the Catholic Church, in general Popes issue Encyclicals to instruct and teach all people of good will about the theological content of the Catholic faith. Sometimes encyclicals also focus on certain topics relevant to their times. Pope Francis' encyclical too is a spiritual document; however, its scope expands beyond it. In the present times as a lot of debate is going on the ill effects of climate change, this encyclical seeks to counterbalance the UNFCCC discussions, which center on the economy and technology. Pope Francis touches at the epitome of the problem rather than giving a symptomatic solution. He is not against all the ideas expressed about sustainable development by scientists or economists. $\mathrm{He}$ is suggesting that mere focus on economic and technological growth without integrating the other aspects of human life may prove to be detrimental to the cause of sustainable development. He notes that,

These are signs that the growth of the past two centuries has not always led to an integral development and an improvement in the quality of life. Some of these signs are also

3 See Edward Carr, "Sustainable Development," in Encyclopedia of Environmental Ethics and Philosophy, eds. J. Baird Callicott \& Robert Frodeman, vol. 2 (Detroit: Gale Cengage Learning, 2009), 295298.

4 See Nilanjan Ghosh \& Anandajit Goswani, Sustainability Science for Social, Economic and Environmental Development (Hershey: IGI Global, 2014), 7-8.

5 See Commission on Sustainable Development's Webpage https://sustainabledevelopment.un.org/intergovernmental/csd/about (accessed 10 February 2016). 
symptomatic of real social decline, the silent rupture of the bonds of integration and social cohesion. ${ }^{6}$

Climate change poses a formidable challenge to the entire humanity. No nation can afford to neglect the warning bells of the impending catastrophe. The richer nations may try to reduce the ill effects of climate change by using enhanced technologies. However, these nations may not be able to buffer themselves against all the ill effects of climate change in the future. ${ }^{7}$ Thus, all the nations especially the poorer nations may have to face severe consequences like mass migration in search of food and water because of the effects of climate change. However, there is still hope. Things can change only if everyone takes initiative to work for the integral development of the society. Pope Francis notes that,

The urgent challenge to protect our common home includes a concern to bring the whole human family together to seek a sustainable and integral development, for we know that things can change. ${ }^{8}$

Scientists, economists and environmentalists offer suggestions to world leaders to make changes in their respective nation's policies to promote sustainable development. Pope Francis too welcomes this move; however, he cautions that the policy changes need to take into account the good of the local community and the future generations. He notes that merely changing policies without studying the impact it may have on the people and the environment may bring more harm than good. He notes that,

The goals of this rapid and constant change are not necessarily geared to the common good or to integral and sustainable human development. Change is something desirable, yet it becomes a source of anxiety when it causes harm to the world and to the quality of life of much of humanity. ${ }^{9}$

Experts blame increasing population as one of the blocks for sustainable development. They note that population explosion leads to further exploitation of natural resources and results in more poverty. ${ }^{10}$ It may be true that rise in population (especially urban population) may increase the consumption of natural resources like water, air and fuels. Increase in population implies generation of more waste thereby destroying the fragile eco-systems. However, population explosion is not the crux of the problem. It is like the tip of the iceberg. The real problem lies in inequitable distribution of resources, which, creates greater damage to the earth. The rich and the powerful inevitably tilt the scale in

6 LS, no. 46.

7 See Irving Mintzer, "Living in a Warming World," in Confronting Climate Change: Risks, Implications \& Responses, eds. Irving Mintzer, Art Kleiner \& Amber Leonard (Cambridge: Cambridge University Press, 1992), 1-14.

8 LS, no. 13.

9 LS, no. 18.

10 See Kailash Chandra Bebarta, Forest Resources \& Sustainable Development: Principles, Perspectives \& Practices (New Delhi: Concept Publishing Company, 2004), 155-156. 
their favor when lawmakers frame policies. In their pursuit to gain more wealth and power, they recklessly exploit the natural resources. Pope Francis notes that the experts need to point towards the unjust economic structures, which deplete the natural resources. He notes that,

To blame population growth instead of extreme and selective consumerism on the part of some, is one way of refusing to face the issues. It is an attempt to legitimize the present model of distribution, where a minority believes that it has the right to consume in a way which can never be universalized, since the planet could not even contain the waste products of such consumption. ${ }^{11}$

Sustainable development is the need of the hour. All nations need to come together to work towards it. However, the onus of taking the lead lies on developed nations. Clemencon stresses in his article that in spite of global political pressure on Western Europe countries to take a back seat in matters of sustainable development, they need to take lead in formulating policies to advance sustainable development and tackle climate change problems. ${ }^{12}$ The developed countries need to pay more funds for they have greater share in creating pollution. If the developed nations insist that all nations need to contribute at par for global climate change problems then there will be no solution to this problem, as the developing nations will never agree with this proposal. Further, it will lead to a vicious circle. The developing nations will justify their actions of polluting the environment in the name of development and better life. Thus, the developed nations need to shoulder their responsibility to lead the nations to integrate development with common good. Pope Francis calls upon the richer nations to take responsibility of their acts done in the past and be generous towards developing nations to develop cleaner technologies. he notes that,

The developed countries ought to help pay this debt by significantly limiting their consumption of non-renewable energy and by assisting poorer countries to support policies and programmes of sustainable development. The poorest areas and countries are less capable of adopting new models for reducing environmental impact because they lack the wherewithal to develop the necessary processes and to cover their costs. ${ }^{13}$

In order to tackle climate change scientists suggest using modern technology where it is possible. Governments of respective nations need to encourage people to use these modern technologies in order to reduce the pollution and contaminations levels in the environment. For instance, governments could give incentives to people who use hybrid vehicles that run on hydrogen or electric power. This can help in bringing down the

11 LS, no. 50.

12 See Raymond Clémençon, "Sustainable Development, Climate Politics and EU Leadership: A Historical Comparative Analysis,” European Journal of Sustainable Development, 5, no. 1 (2016): 125-144.

13 LS, no. 52. 
volume of carbon dioxide in the air and effectively reducing air pollution. ${ }^{14}$ Similarly, governments need to give tax benefits to people using solar energy. Further, governments also need to encourage scientists to develop technology to treat sewage water in order to reduce the contamination of rivers. At the same time, governments also need to educate people not to pollute rivers, as they are the major sources of fresh water. For instance, the river Ganges is a major river in India, which supplies fresh water for drinking, agricultural and industrial purposes. However, the high level of contamination in the water is causing many health hazards to people and animals who consume its water. ${ }^{15}$ Further, scientists also need to develop technology to purify seawater so that many drought prone areas may get water for agricultural purposes. ${ }^{16}$ Pope Francis acknowledges with gratitude the immense role scientists are playing in promoting cleaner technologies and improving the quality of life. He notes that,

Technology has remedied countless evils which used to harm and limit human beings. How can we not feel gratitude and appreciation for this progress, especially in the fields of medicine, engineering and communications? How could we not acknowledge the work of many scientists and engineers who have provided alternatives to make development sustainable? ${ }^{17}$

Pope Francis encourages the prudent use of technology for the good of humanity. However, he cautions the world community not to disregard the ancient wisdom and values. Science and technology are important however, these cannot satisfy every aspect of life. Societal values like justice, peace and harmony are equally important to promote true human development. Therefore, the world community needs to analyze both the merits and demerits of any technology before using it for public use. For instance, a part of the scientific community promotes the use of genetically modified (GM) seeds whereas some others claim that such seeds may be harmful. ${ }^{18}$ There are certain safety regulators especially in the U.S. and Europe who ascertain the impact of GM crops on human beings. However, there are no long-term studies, which, prove that GM crops and food are fully safe. In some countries, GM seeds have brought great harm to farmers as well. ${ }^{19}$ As the debate continues about the consumption of GM crops and food, world leaders need to be more prudent while permitting the use of GM crops and food in their respective countries. ${ }^{20}$ Pope Francis welcomes the prudent use of technology and notes that,

14 See Yin Yin Cai, "The Coase Dilemma: Two Kinds of Technologies of Reducing Pollution," in Environment, Energy \& Applied Technology, eds. Wen-Pei Sung \& Jimmy Kao (London: Taylor \& Francis Group, 2015), 283-285.

15 See P. K. Agarwal, "Ganga Pollution Control," in Environment Protection \& Pollution Control in the Ganga, ed. P. K. Agarwal (New Delhi: M. D. Publications Pvt. Ltd., 1994), 99-116.

16 Ibid.

17 LS, no. 103.

18 See Keith Anderson, ed., Genetically Modified Crop: Assessing Safety (London: Taylor \& Francis, 2002), ix-x.

19 See Lillian Forman, Genetically Modified Foods (Edina: Abdo Consulting Group, Inc., 2010), 46-55.

20 LS, no. 134. 
Nobody is suggesting a return to the Stone Age, but we do need to slow down and look at reality in a different way, to appropriate the positive and sustainable progress which has been made, but also to recover the values and the great goals swept away by our unrestrained delusions of grandeur. ${ }^{21}$

Pope Francis gives a spiritual angle to the inter-relatedness of organisms as creatures of God. He notes that the inherent goodness of God is present in each organism. He maintains that this inherent goodness needs to be the basis of developing ecosystems to promote sustainable development. Pope Francis stresses on the dignity of human person and respect for every organism in this world. Thus, Pope Francis seeks integral development of all the organisms present in this world. He notes that the yardstick to work for sustainable development should not be mere profit but appreciating the real worth of every organism because God's inherent goodness is present in every organism. ${ }^{22}$ This calls for a new pattern of education, which is inclusive and holistic. Further, as all have the common destiny as partners on this earth, no one has the right to destroy the balance of the fragile eco-systems. He notes that scientist would do well if they carry out their research by valuing the dignity of every organism. He notes that,

Ongoing research should also give us a better understanding of how different creatures relate to one another in making up the larger units which today we term 'ecosystems'... Each organism, as a creature of God, is good and admirable in itself... So, when we speak of 'sustainable use', consideration must always be given to each ecosystem's regenerative ability in its different areas and aspects. ${ }^{23}$

Pope Francis links inter-generational solidarity with sustainable development. Intergenerational solidarity calls for a development plan, which balances the welfare of both the present and the future generations. ${ }^{24}$ Political leaders and scientists need to formulate policies and plans, which, do not destroy the eco-systems to bring quick profits to the local communities but may rob the future generations of their legitimate right of existence. For instance, preserving tigers is important for maintaining a healthy biodiversity habitat of the forests. ${ }^{25}$ If leaders make profit making as the sole criteria for making policies then there is a danger of destroying the tiger habitat by clearing the forests for agricultural or industrial purposes. Deforestation may give rise to industrialization and improve the economy provisionally. However, in the longer run it is bound to create more problems because of the destruction of eco-systems. Shin notes in his research on the environmental policies of East Asian countries that rapid

21 LS, no. 114.

22 See Krisnan Saigal, Sustainable Development: The Spiritual Dimension (Delhi: Kalpaz Publications, 2008), 29-46.

23 LS, no. 140.

24 See Sandor Fulop, "The Institutional Representation of Future Generations," in Human Rights \& Sustainability: Moral Responsibilities for the Future, eds. Gerhard Bos \& Marcus Duwell (Abingdon: Routledge, 2016), 195-211.

25 See Eleanor Shoreman-Ouimet \& Helen Kopina, Culture and Conservation: Beyond Anthropocentrism (Abingdon: Routledge, 2016), 146-161. 
industrialization has put immense stress on the environment and resulted in degradation of soil, water and other natural resources. ${ }^{26}$ Thus, leaders need to devise alternative ways to benefit the local community without destroying the fragile eco-system of the region. McCool in his research on the Bob Marshall Wilderness Complex in Montana, U.S. notes that the locals stopped exploiting natural resources because the state increased the scope of tourism in these areas without causing any harm to the wildlife or the environment. ${ }^{27}$ Thus, Pope Francis stresses on inter-generational solidarity because this world is a gift for all generations and not any one-generation. He notes that,

We can no longer speak of sustainable development apart from intergenerational solidarity. Once we start to think about the kind of world we are leaving to future generations, we look at things differently; we realize that the world is a gift which we have freely received and must share with others. ${ }^{28}$

Along with inter-generational solidarity, there is also need for intra-generational solidarity. The present culture of over consumption by certain people deprives many of their basic needs. Chicilnisky notes in her research that developed nations import natural resources cheaply from developing nations thereby increasing poverty there and giving rise to more domestic consumption. ${ }^{29}$ This leads to generation of more waste in the developed countries. These nations then try to dump this waste back again in developing nations, which increases the risk of environmental hazards to people who are struggling to meet the basic needs of their daily lives. Thus, there is need to promote intragenerational solidarity especially to the weak and the poor.

The world leaders are trying to fix the problem of rising carbon dioxide levels by employing the strategy of marketing carbon credits. Pope Francis strongly criticizes such a strategy, which he notes as "a ploy which permits maintaining the excessive consumption of some countries and sectors." 30 Carbon trading means that a trade is free to pollute the environment as long as it can buy carbon credits from elsewhere. This market-oriented strategy to reduce the overall emission of carbon dioxide is bound to have a disastrous effect on the environment. Further, the polluter nations can come out clean without taking responsibility for their acts. Bachram notes in her research that richer nations have abused the carbon trading system to tilt the balance in their favor and put the dirty job of cleaning the pollution on the developing nations. ${ }^{31}$ Fearnside

26 See Sangbum Shin, "Environment Policy in East Asia: Institutions in Comparative Perspective," in Routledge Handbook of Environment \& Society in Asia, eds. Paul Harris \& Graeme Lang (Abingdon: Routledge, 2015), 71-84.

27 See Stephen McCool, "Tourism \& Sustainability in a Forested Protected Area," in Forests \& Society: Sustainability \& Life Cycles of Forests in Human Landscapes, eds. Kristiina Vogt et al. (Oxforshire: CABI, 2007), 259-261.

28 LS, no. 159.

29 See Graciela Chichilnisky, "Environment \& Global Public Goods," in Environment: Inequality \& Collective Action, eds. Marcello Basili, Maurizio Franzini \& Alessandro Vercelli (Abingdon: Routledge, 2006), 177-194.

30 LS, no. 171

31 See Heidi Bachram, "Climate Fraud \& Carbon Colonialism: The New Trade in Greenhouse Gases," Capitalism Nature Socialism, 15, no. 4 (2004): 5-20. 
questions the rationale of the world organizations, which set the standards of clean development mechanisms without setting any minimum criteria to define sustainable development. ${ }^{32}$ Some of the measures taken by successive world organizations may be scientifically correct but lack moral correctness.

Pope Francis suggests world leaders need to act quickly to reduce the use of fossil fuels and go for cleaner energies. He urges the richer nations to help the developing nations to acquire cleaner technologies like tapping solar energy at subsidized rates. He notes that,

The pace of consumption, waste and environmental change has so stretched the planet's capacity that our contemporary lifestyle, unsustainable as it is, can only precipitate catastrophes, such as those which even now periodically occur in different areas of the world. The effects of the present imbalance can only be reduced by our decisive action, here and now. ${ }^{33}$

The world is becoming a global village. ${ }^{34}$ International organizations, political leaders, scientists, economists and other experts acknowledge the importance of inter-relatedness among people of all the nations. No nation can afford to isolate itself from others. It is increasingly becoming an inter-dependent world and therefore co-ordination among nations is important. All the nations need to take prompt action to tackle the environmental problems that the world is presently facing. The best way forward is that leaders of all the nations need to have a fruitful dialogue among them before framing policies. Further, the political, economic and social conditions differ, political leaders need to evolve consensus to put into actions the various plans and policies for combating global warming. Pope Francis notes his concern about the one-upmanship of some rich and powerful nations in formulating environmental policies without considering the negative impact it may have on the whole world, especially the developing nations. He notes that,

An interdependent world not only makes us more conscious of the negative effects of certain lifestyles and models of production and consumption which affect us all; more

importantly, it motivates us to ensure that solutions are proposed from a global perspective, and not simply to defend the interests of a few countries. Interdependence obliges us to think of one world with a common plan. Yet the same ingenuity which has brought about enormous technological progress has so far proved incapable of finding effective ways of dealing with grave environmental and social problems worldwide. ${ }^{35}$

In our profit-oriented world, political leaders tend to place domestic interests above the global environmental concerns. ${ }^{36}$ Political leaders and multi-national business

32 See Philip Fearnside, "Saving Tropical Forests as a Global Warming Countermeasure: An Issue that Divides the Environmental Movement," Ecological Economics 39 (2001): 167-184.

33 LS, no. 161.

34 See Paul Kevin Wapner, Environment Activism \& World Civic Politics (Albany: State University of New York Press, 1996), 117-151.

35 LS, no. 164.

36 See David Goldbatt, Social Theory \& the Environment (Canbridge: Polity Press, 1996), 10-13. 
establishments give more importance to their economic well-being even if it means to harm the environment. Pope Francis strongly criticizes such a rationale, which seeks short-term good of a certain section of people and neglects the welfare of others. He notes that,

International negotiations cannot make significant progress due to positions taken by countries which place their national interests above the global common good. Those who will have to suffer the consequences of what we are trying to hide will not forget this failure of conscience and responsibility. ${ }^{37}$

Unabated greed for profit is promoting consumerism. Electoral gains are further deteriorating the situation. Winfield notes in his research on the link between poll politics and sustainable development that environment ministers in Canada often find it difficult to convince their cabinet colleagues to frame policies, which may have no shortterm economic benefit, but on the other hand could result in more transitional costs. ${ }^{38}$ In U.S., too short election cycles often put pressure on politicians not to take bold decisions, which may be unpopular among the local people. In order to reap political benefits politicians choose to please their voters rather than framing polices, which may substantially benefit the environment in the end. ${ }^{39}$ Political leaders in other parts of the world too, often choose to ignore long-term sustainable development programs in order to appease their voters. They frame policies, which may bring them back to power. The successive governments leave the task of framing proper policies, which may have longterm environmental benefits, to their successors. However, political leaders need to note that their hesitation to frame proper policies is akin to the woodcutter who cut the very branch on which he was sitting. Pope Francis denounces such manipulation on the part of politicians for electoral gains and notes that,

A politics concerned with immediate results, supported by consumerist sectors of the population, is driven to produce short-term growth. In response to electoral interests, governments are reluctant to upset the public with measures which could affect the level

of consumption or create risks for foreign investment. The myopia of power politics delays the inclusion of a far-sighted environmental agenda within the overall agenda of governments. ${ }^{40}$

Pope Francis calls on all world leaders, scientists and economists to take bold steps to plan for sustainable development with the larger interests of the whole humanity and not just the rich and the powerful. He asks them to be open to ideas from sections of the people while framing policies on environment. He notes that,

37 LS, no. 169.

38 See Mark Winfield, "Polls, Politics \& Sustainability," in Innovation, Science, Environment: Special Edition, Charting Sustainable Development in Canada, 1987-2007, eds. Glen Toner \& James Meadowcroft (Montreal \& Kingston: McGill-Queen's University Press, 2009), 72-94.

39 See Byron Daynes, Glen Sussman \& Jonathan West, American Politics \& the Environment, 2nd ed. (Albany: State University of New York Press, 2016), 71-96.

40 LS, no. 178. 
It is a matter of openness to different possibilities which do not involve stifling human creativity and its ideals of progress, but rather directing that energy along new channels. ${ }^{41}$ Thus, $L S$ is offering a different concept of sustainable development, which includes all and deprives justice to none. Pope Francis urges world leaders to focus on the welfare of the people and the environment while they frame policies. He calls on them not to leave behind anyone but involve everyone to find ways to build a more harmonious world.

\section{Conclusion}

The narrative of $L S$ is that climate justice is not possible because of the moral depravity in the society. Pope Francis notes that St. Francis, "shows us just how inseparable the bond is between concern for nature, justice for the poor, commitment to society, and interior peace." $42 \mathrm{He}$ questions the present concept of sustainable development, which does not take into account the root cause of the problems but tries to find a symptomatic solution. Pope Francis notes that intra-generational and inter-generational solidarity needs to be the standard for framing environmental policies. He cautions world leaders and planners not to give priority to moneymaking and profit as the criteria to stall ecological projects. He calls on the whole humanity to choose a simple way of life like St. Francis, which promotes morality, spirituality and integral ecology. He calls the world community to draw plans for sustainable development, which give importance to dignity of every person, social equity and environmental protection. 